\title{
라틴아메리카 사회정책에 함의된 시사점과 국별협력전략 지원방안 : 빈곤과 불평등 극복방안을 중심으로
}

정 상 희 (KOICA 중남미팀 정책연구원)

\section{목 차}

1. 들어가며

2. 라틴아메리카의 빈곤과 불평등

3. 볼리비아의 빈곤과 불평등

4. 사회정책에 함의된 시사점과 국별협력전략 지원방안

5. 결론

\section{1. 들어가며}

2000년대 국제사회는 최빈국(Least Developed Countries: LDCs)과 취약국 중심으로 공적 개발원조(Official Development Assistance: ODA)를 확대하는 노력을 보이면서, 흔히 중소 득국가1)로 분류되는 라틴아메리카에 대한 관심은 줄어들고 있다. 그러나 라틴아메리카에서 빈 곤과 불평등은 항상 논의되고 있는 핵심적인 과제 중 하나이다. 유엔새천년개발목표 (Millennium Development Goals: MDGs) 보고서에 의하면, 이 지역의 빈곤과 소득 불평등 상황은 충분히 개선되지 않고 있다. 이와 관련하여, 이 지역 국가들은 라틴아메리카의 경우 동 일한 중소득국의 범주에 속하나 국가별로 소득격차가 크고 불평등 정도가 다르며, 세계시장에 편입하는 과정에서 다양한 경제, 사회적인 차이가 발생했으므로 이러한 상황에 대한 고려가 필

1) 본 글에서 "중소득국(Middle Income Countries: MICS)" 이란 개발원조위원회(DAC)의 수원국 리스트에 따른 중 소득국의 범주를 지칭한다. 
요하다고 주장하고 있다. ${ }^{2)}$ 따라서 국가별 특성에 대한 면밀한 분석 없이 1 인당 국민총소득 (GNI per capita)이라는 경제적인 지표로 수원국을 분류하는 개발원조위원회(Development Assistance Committee: DAC)의 현재 기준에 대해서도 이의를 제기하고 있다.

외형상 통계로 볼 때, 1990년부터 2010년까지 라틴아메리카는 경제성장을 이루면서 약 4천 만명 이상이 빈곤계층에서 벗어났으며 여타 지역과 비교할 때 사회발전 지표가 양호하지만, 소 득 불평등의 경우 전 세계에서 가장 심각한 수준에 있다. 결론적으로 이 시기 동안 라틴아메리 카에서 이루어진 성장과 거시경제 지표의 개선은 더 나은 소득분배, 생산적인 일자리 창출, 노 동조건 개선, 생산성 향상과는 직결되지 않았다. 3) 또한 유엔라틴아메리카 경제위원회 (Comisión Económica Para América Latina y el Caribe: CEPAL)와 유엔개발계획(UN Development Programme: UNDP)은 라틴아메리카에 수직적인(vertical) 불평등과 수평적 인(horizontal) 불평등이 존재하고 있으며, 이는 세대를 거쳐 재생산된다고 분석하고 있다.

이러한 상황에 대한 고려 하, 본 글은 보편론적인 접근의 맥락에서 라틴아메리카의 빈곤과 불 평등 상황을 분석하고, ${ }^{4)}$ 개별사례 국가로서 볼리비아의 빈곤과 불평등에 대한 특수성을 고찰하 는 것을 목적으로 하였다. 또한 라틴아메리카 국가들의 시각에서 이러한 과제를 해결하기 위해 모색되었던 조건부 현금지급 프로그램(Conditional Transfer Program: CTP) 등 사회정책들 의 사례를 파악하고 이러한 정책에 함의된 시사점을 도출하여 국가협력전략(Country Partnership Strategy: CPS)5)에서 가능한 지원방안을 제시하고자 하였다.

따라서 2장에서는 다차원적인 빈곤과 불평등 정도를 측정하기 위해 활용되고 있는 국제적인 지표 이외에 스페인과 포루투갈의 식민지 경험에서 기인하고 있는 역사, 문화적인 요소를 고려 하는 동시에 산업화와 신자유주의 정책의 도입 과정에서 노동시장을 중심으로 나타났던 변화를

2) Titelman, Daniel(2011) 참조.

3) Dina Nuñez, Ignacio, coord.(2004: 10-11).

4) 윤택동 \& Nelson dos Reis, Carlos(2005); 박윤주(2011) 참조. 라틴아메리카의 빈곤과 불평등 관련한 국내 연구 를 간략히 소개한다면, 윤택동은 식민지 시대부터 유래된 라틴아메리카의 정치, 경제, 사회적 이분구조를 설명하면 서 세계화와 신자유주의 영향으로 이 지역의 사회적 소외현상이 악화되었다고 설명하고 있으며, 성장에 따른 분배 방법에 대해 고민할 필요성을 제기하고 있다. 한편, 박윤주는 라틴아메리카의 빈곤과 불평등 상황, 그리고 사회, 경제 구조의 모순을 극복하기 위해 모색했던 다양한 방안을 시장주의적 접근과 참여적 발전 접근법으로 구분하여 고찰하고 있다.

5) 정유아(2010: 3). 본 전략은 원조지원의 핵심적인 행정도구로 고려되고 있으며, 국내에는 선진화 방안의 수단으로 2006년에 도입되었다. 
토대로 라틴아메리카의 빈곤과 불평등 상황을 분석하였다. 3장에서는 라틴아메리카의 빈곤과 불평등에 대한 보편론적인 접근 틀내에서 볼리비아의 특수한 역사적인 배경, 사회, 경제 구조, 인종, 지역 간 갈등 양상을 분석함으로써, 세대 간에 걸쳐 재생산되고 있는 빈곤과 불평등의 상 황 그리고 그 특성을 고찰하였다. 한편, UNDP 보고서에는 경제위기 발생 전 이 지역의 빈곤과 불평등 상황이 개선되어 왔던 이유와 관련하여, 당시 국가별로 추진되어 왔던 사회정책과 교육 의 확산 그리고 이에 대한 투자가 증가되었기 때문이라고 언급하고 있다. 또한 향후에도 이 지 역 국가들은 지속가능한 발전을 위해 역내와 국가별 불평등 개선을 최우선 과제로 고려하고 있 으며, 이러한 과정에서 사회정책의 역할과 중요성을 강조하고 있다. 따라서 4장에서는 빈곤과 불평등을 극복하기 위해 추진되어 왔던 사회정책들을 유형별로 분류하고 그 특성에 대해 분석 했으며, 이들의 시각에서 수립되어 온 주요한 사회정책에 함의된 시사점을 도출하고, 특히 볼리 비아 사례를 토대로 CPS내에서 한국의 지원방안을 제시하였다.

\section{2. 라틴아메리카의 빈곤과 불평등}

DAC에서 발표한 2011 2013년 수원국 리스트에 따르면, 라틴아메리카 국가 중 최빈국인 $(\mathrm{LDCs})$ 인 아이티를 제외한 대부분 국가들이 중소득국(MICs)의 범주에 속하고 있다.6) 2009 2010년 리스트와 비교할 때, 상위중소득국(Upper Middle Income Countries: UMIC) 에 속했던 바베이도스와 트리니다드 토바고가 수원국에서 제외되면서 중소득국은 전체적으로 2 개국이 감소하였다. 이외도 벨리즈는 하위중소득국(Low Middle Income Countries: LMICs) 으로 격하되었으나 콜롬비아, 도미니카 공화국, 에콰도르, 페루 등 4개국이 UMIC로 격상하였 다. 이에 따라 LMIC국가 수는 11 개국에서 8 개국으로 감소했으며, UMIC의 경우에는 22 개국에 서 23 개국으로 증가하였다.

6) DAC(2011), DAC list of ODA recipients, http://www.oecd.org(2012년 7월 10일). 
〈표 1〉DAC의 수원국 리스트(2009-2010/2011-2013): 라틴아메리카

\begin{tabular}{|c|c|c|c|c|}
\hline \multicolumn{3}{|c|}{ 2009년 2010년 } & \multicolumn{2}{|c|}{ 2011 2013년 } \\
\hline $\begin{array}{l}\text { 최빈국 } \\
\text { (LDCs) }\end{array}$ & $\begin{array}{c}\text { 하위중소득국 } \\
\text { (LMICS) (per } \\
\text { capita GNI \$936- } \\
\text { \$3,705 in 2007) }\end{array}$ & $\begin{array}{l}\text { 상위중소득국 } \\
\text { (UMICs) } \\
\text { (per capita GNI } \\
\$ 3,706-\$ 11,455 \\
\text { in 2007) }\end{array}$ & $\begin{array}{c}\text { 하위중소득국 } \\
\text { (LMICs) } \\
\text { (per capita GNI } \\
\$ 1006-\$ 3,975 \text { in } \\
2010)\end{array}$ & $\begin{array}{c}\text { 상위중소득국 } \\
\quad \text { (UMICs) } \\
\text { (per capita GNI } \\
\$ 3,976-\$ 12,275 \\
\text { in 2010) }\end{array}$ \\
\hline 아이티 & $\begin{array}{c}\text { 볼리비아 } \\
\text { 콜롬비아 } \\
\text { 도미니카 공화국 } \\
\text { 에콰도르 } \\
\text { 엘살바도르 } \\
\text { 과테말라 } \\
\text { 가이아나 } \\
\text { 온두라스 } \\
\text { 니카라과 } \\
\text { 파라과이 } \\
\text { 페루 }\end{array}$ & $\begin{array}{c}\text { 앵귈라 } \\
\text { 안티구아 바부다 } \\
\text { 아르헨티나 } \\
\text { 바베이도스 } \\
\text { 벨리즈 } \\
\text { 브라질 } \\
\text { 칠레 } \\
\text { 코스타리카 } \\
\text { 쿠바 } \\
\text { 도미니카 연방 } \\
\text { 그레나다 } \\
\text { 자메이카 } \\
\text { 멕시코 } \\
\text { 몬세라트 } \\
\text { 파나마 } \\
\text { 세인트 킷츠 네비스 } \\
\text { 세인트 루시아 } \\
\text { 세인트 빈센트 그레나딘 } \\
\text { 수리남 } \\
\text { 트리니다드 토바고 } \\
\text { 우루과이 } \\
\text { 베네수엘라 }\end{array}$ & $\begin{array}{c}\text { 벨리즈 } \\
\text { 볼리비아 } \\
\text { 엘살바도르 } \\
\text { 과테말라 } \\
\text { 가이아나 } \\
\text { 온두라스 } \\
\text { 니카라과 } \\
\text { 파라과이 }\end{array}$ & $\begin{array}{c}\text { 앵귈라 } \\
\text { 안티구아 바부다 } \\
\text { 아르헨티나 } \\
\text { 브라질 } \\
\text { 칠레 } \\
\text { 콜롬비아 } \\
\text { 코스타리카 } \\
\text { 쿠바 } \\
\text { 도미니카 연방 } \\
\text { 도미니카 공화국 } \\
\text { 에콰도르 } \\
\text { 그레나다 } \\
\text { 자메이카 } \\
\text { 멕시코 } \\
\text { 몬세라트 } \\
\text { 파나마 } \\
\text { 페루 } \\
\text { 세인트 킷츠 네비스 } \\
\text { 세인트 루시아 } \\
\text { 세인트 빈센트 그레 } \\
\text { 나딘 } \\
\text { 수리남 } \\
\text { 우루과이 } \\
\text { 베네수엘라 }\end{array}$ \\
\hline
\end{tabular}

출처: OECD/DAC의 수원국 리스트(List of ODA recipients)를 토대로 필자작성 
이처럼 경제지표를 토대로 볼 때, 라틴아메리카의 전반적인 상황은 개선된 것으로 보이며, 이 외에도 인간개발지수(Human Development Index: HDI), 기대수명, 5세 이하 아동사망률, 초등교육 이수율 등 사회발전 지표도 타 개도국의 평균을 상회하고 있다. 한편, MDGs 달성현 황은 초등교육기관에서 양성평등실현(MDG3), 안전한 식수 접근율(MDG7), 인터넷 사용 비율 (MDG8)에서 이미 목표를 달성했거나 목표에 근접하는 것으로 평가되고 있으며, 비록 2009년 세계적인 경제위기 발생 이후 개선속도가 미흡하나 대체로 목표달성에 근접하고 있는 것으로 분석되고 있다. 7) 이를 두고 국제사회에서는 흔히 라틴아메리카를 “중소득국의 대륙” 으로 지칭 하고 있다.

CEPAL의 통계에 의하면, 1990 년 빈곤비율은 전체인구의 약 $48 \%$ 에 해당하는 2 억명에서 2010년 1억 8천만명으로 2천만명이 감소했으나 여전히 전체인구의 $31.4 \%$ 를 차지하고 있으며, 이중 극빈층 비율은 $12.3 \%$ 에 달하고 있다. ${ }^{8)}$ 또한 2011년 빈곤비율은 전년대비 $1 \%$ 가 감소한 $30.4 \%$, 극빈층의 경우는 오히려 $0.5 \%$ 가 상승한 $12.8 \%$ 로 전망되고 있다. ${ }^{9}$ 물론 국가별 격차가 존재하나, 위의 통계는 라틴아메리카의 인구 3 명당 1 명이 여전히 빈곤계층에 속해 있음을 의미 하고 있다.

국가별 빈곤비율은 상이한 격차를 보이고 있어 우루과이(8.6\%), 아르헨티나(8.6\%), 칠레 (11.5\%), 코스타리카(18.9\%)는 그 비율이 낮은 편이나, 볼리비아(54\%), 파라과이(54.8\%), 니카 라과(61.9\%), 온두라스(67.4\%)는 역내평균을 훨씬 상회하고 있다. 10$)$ 한편, 소득 불평등 정도는 세계적으로 가장 심각한 수준에 있는데, 실례로 2004년 지니계수(GINI Coefficient)를 기준으 로 보면 라틴아메리카는 사하라 사막 이남 아프리카(Sub-Saharan Africa)보다 그 지수가 높 았다. ${ }^{11)}$

앞에서 언급했던 것처럼, 라틴아메리카의 빈곤과 불평등은 국가별 격차 뿐 아니라 동일 국가 내에서도 수직과 수평적인 불평등이 발생하고 있으며, 이는 세대 간에 걸쳐 전달되고 있다. 이

7) $\operatorname{UN}(2010: 43)$

8) CEPAL(2011: 11 13).

9) $\operatorname{CEPAL}(2011:$ 11 13). 본 보고서에는 2011년 이 지역의 극빈층 비율이 소폭 증가한 이유를 식량과 기초생활 물품 의 가격이 상승했기 때문이라고 지적하고 있다.

10) CEPAL(2011: 13). 칠레, 코스타리카, 볼리비아, 니카라과는 2009년 통계를 활용했으나, 나머지 국가는 2010년 기준으로 작성하였다.

11) Lustig, Nora(2011) 참조. 2004년 지니계수(Gini Coefficient)와 관련하여, 라틴아메리카와 캐리비안(Latin America and the Caribbean)은 53.2였으며, 사하라 사막 이남 아프리카(Sub-Saharan Africa)는 44.7을 기록 하였다. 
를 두고 UNDP에서는 이 지역의 다차원적(multi-dimensional)인 불평등은 경제, 사회적인 이동 가능성이 제한되면서 반복적으로 발생되고 있으며, 따라서 “높고(high)”, “지속적 (persistent)”이며, “비탄력적(inflexible)”인 특성을 보인다고 분석하고 있다. 12) 소득, 교육, 지식의 불평등한 배분 외에도 노동시장에서 교육과 지식을 충분히 활용할 수 없는 구조적인 모 순과 대체적으로 낮고 변동성이 컸던 경제성장의 패턴도 이러한 상황을 악화시키는 요인으로 작용하였다. ${ }^{13)}$

빈곤과 불평등의 원인은 스페인과 포루투갈의 식민시대, 산업화 그리고 워싱턴 컨센서스 (Washington Consensus)라는 신자유주의 정책도입 이후로 구분하여 설명할 수 있다. 스페인 과 포루투갈의 식민기간 동안에는 소수의 정복자 계층과 다수의 피지배계층으로 구성된 이중적 인 사회구조가 형성되었다. 전반적으로 지배국의 부흥을 위해 원자재 수출 중심으로 경제가 운 용되면서 대규모 농장주와 광산자본가 등 소수 지배계층을 중심으로 자본축적이 용이해졌고, 이러한 과정에서 장기간에 걸친 불평등이 구조화되었다. 산업화와 신자유주의 정책은 라틴아메 리카의 전반적인 체제에 큰 변화를 가져왔다. 특히, 국가권한의 축소, 민영화, 구조조정 (restructuring), 무역자유화를 핵심으로 하고 있는 신자유주의 정책의 도입은 이념 논쟁으로 도 확대되면서, 계층, 인종, 지역 간의 정치, 경제, 사회적인 갈등을 야기하였다. 또한 고용주의 권한 강화, 새로운 고용체계와 임금제도 도입, 노동시장의 유연화와 더불어 비공식 부문에서 고 용기회가 증가하면서 이 지역에서는 새로운 형태의 사회적인 소외계층이 형성되기 시작하였 다. 14)〈그림1〉은 1990년부터 2009년까지 생산성이 낮은 산업부문(비공식부문)과 생산성이 중 간, 그리고 높은 산업부문 종사자간의 실질 임금 추이를 비교한 그래프이다. 한편, 1990년 도시 지역 노동자를 기준으로 생산성이 낮은 산업부문의 종사자 비율은 48.1\%였으나, 2009년 이 비 율은 $42.7 \%$ 로 감소하였다. 그럼에도 불구하고, 산업부문 간 임금격차는 지속되고 있으며, 경제 위기가 발생했던 2009년에는 이 격차가 소폭이지만 오히려 확대되는 경향을 보이고 있다. ${ }^{15)}$

이상과 같이 신자유주의 정책이후 비공식 부문 등 생산성이 낮은 부문을 중심으로 노동자의 절반정도가 종사하면서 고용기회의 확대는 오히려 사회 권리와 혜택으로부터 소외된 계층을 양

12) UNDP(2010: 19 21).

13) Weller, Jurgen(2011: 36-37).

14) 윤택동 \& Nelson dos Reis, Carlos(2005: 80-81). 본 연구에서는 라틴아메리카가 세계화로 인해 전통적인 형 태의 사회적 소외와 새로운 소외현상을 감당해야 하는 이중고에 빠져있다고 표현하고 있다.

15) CEPAL(2011: 25 27). 라틴아메리카 경제구조의 특성 중 하나는 산업부문간 생산성 격차가 큰 것이다. 기술과 시장 접근성에 따라 보통 3가지 부문으로 분류하고 있는데, 생산성이 높은 부문(수출기업, 200명 이상 노동자 고 용)은 전체 생산의 $66.9 \%$ 와 고용의 $19.8 \%$ 를 차지하고 있으며, 생산성이 중간인 경우(중소기업)는 생산의 $22.5 \%$ 와 전체고용의 $30 \%$ 에 기여하고 있다. 반면 생산성이 낮은 부문(비공식부문)은 생산의 $10.6 \%$ 를 차지하며, 전체 고용의 $50 \%$ 를 창출하고 있다. 
산하는 결과를 가져오게 되었고, 이는 새로운 형태의 양극화 현상을 초래하였다. 이외에도 가 스, 수도, 전력부문의 공공기업 민영화는 이 분야의 비용을 증가시키면서 저소득층, 비공식부문 의 노동자, 실업자 등 취약계층의 빈곤을 악화시키는 요인이 되었다.

\section{〈그림 1〉라틴아메리카 국가의 경제부문별 실질임금 추이}

(단위: 2005년 USD)

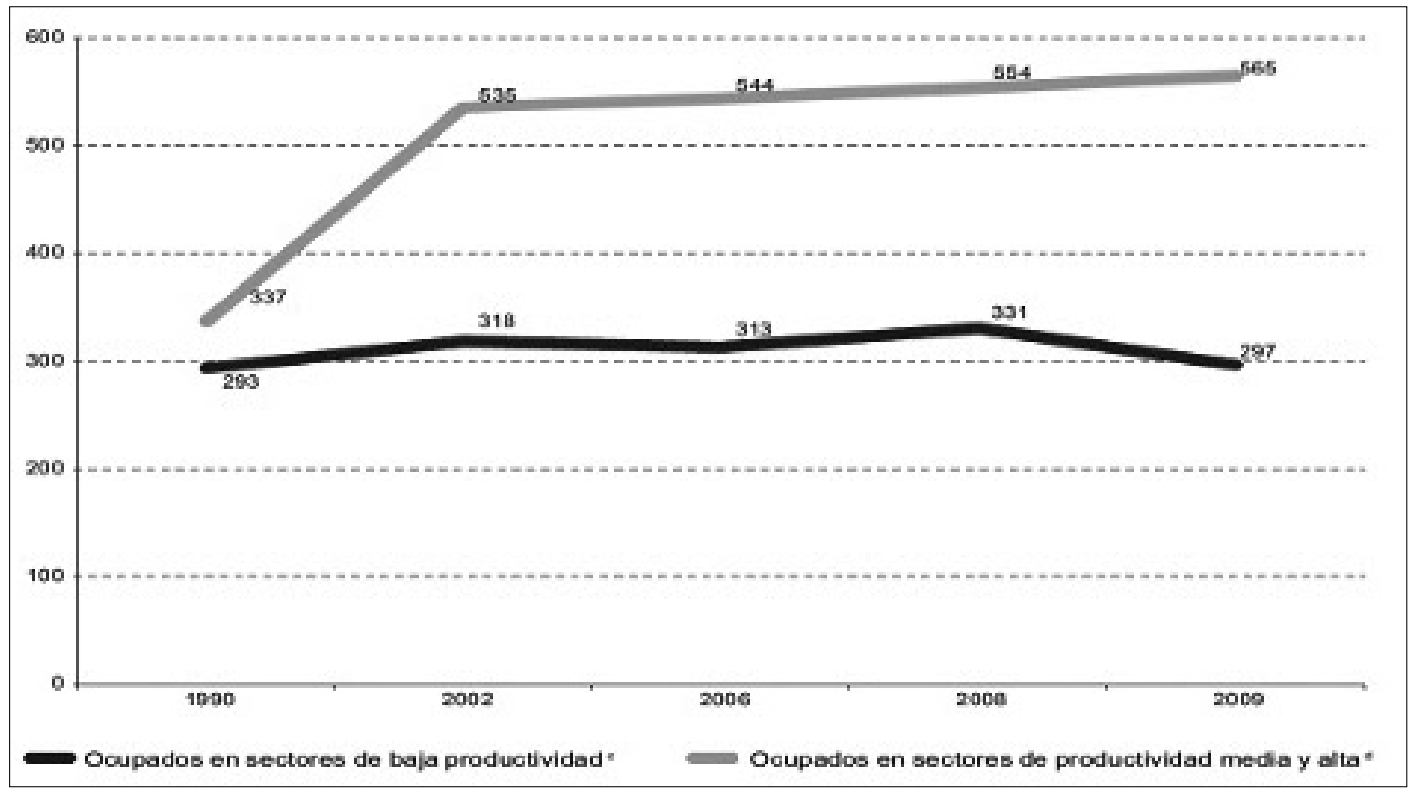

출처: CEPAL(2011)

*도시지역 15세 성인 기준, 18개국 평균(1990년, 2002년, 2006년, 2008년, 2009년)

**파란색선: 생산성이 낮은 부문(노동자 5 명 이하 소기업, 미숙련 자영업자, 전문기술을 보유 하지 않은 무급의 가정 내 노동자 등)

***주황색선: 생산성이 중간과 높은 부문(공공기관 노동자, 노동자 5 명 이상 고용주 및 5 명 이상 기업의 노동자, 독립적인 전문직, 기술자 등)

이와 같이 1980년대 소위 "잃어버린 10년(The lost decade)"으로 불리고 있는 부채위기를 극복하는 과정에서 새롭게 도입되었던 신자유주의 체제는 라틴아메리카에 또 다른 형태의 빈곤 과 불평등을 야기하였다. 이후 발전을 위한 새로운 대안세력으로 등장한 좌파와 중도좌파 정부 하에 라틴아메리카에는 급격한 체제변화가 이루어지고 있으며, 이러한 과정에서 다시 불거지고 있는 인종, 지역, 계층 간 갈등은 국가발전 과정에서 반복적으로 나타났던 또 다른 형태의 사회 적인 현상으로 볼 수 있다. 


\section{3. 볼리비아의 빈곤과 불평등}

이 장에서는 개별국가 사례로서 볼리비아의 역사적 배경, 사회, 경제구조, 인종, 지역 간 갈등 양상을 분석하고 라틴아메리카의 빈곤과 불평등에 대한 보편론적인 시각의 틀에서 볼리비아라 는 개별 국가의 특성에서 기인하고 있는 빈곤과 불평등의 특수성을 고찰하고자 한다. 즉, 볼리 비아에서는 어떠한 형태의 빈곤과 수직, 수평적인 불평등이 나타나고 있으며 이것이 어떻게 세 대 간에 걸쳐 재생산되고 있는지를, 그리고 신자유주의 정책 이후에는 어떠한 형태의 새로운 불 평등이 나타나고 있는가를 논의하고자 한다.

우선 다차원적인 시각에서 볼리비아의 수평적인 축에서의 불평등은 인종, 성, 출신지(지역)와 같은 역사적인 요인, 도시 주변부의 확장, 노동시장에서 공식과 비공식 부문의 대두, 세계시장 에 편입하는 과정에서 새롭게 출현한(emergent) 경제, 사회적인 요인으로부터 기인하고 있으 며, 수직적인 불평등은 교육, 소득창출, 직업과 같은 물질적인 요인과 기호(취향), 삶의 양식, 정 체성과 같은 상징적인 요인에서 발생되고 있다. ${ }^{16)}$ 이러한 불평등은 특히 역사적으로 취약계층 이라 고려되었던 원주민, 여성, 농촌주민에게 부정적인 영향을 끼치게 되었다. 한편, 교육, 소득 창출, 직업 등 물질적인 요인에 대한 접근기회가 제한되면서 발생하고 있는 수직적인 불평등은 인적자본 축적과 분절화된 노동시장 진입기회에서 수평적인 불평등을 야기하면서 청년과 노년 층에게도 영향을 끼쳤다. 이외에도 문화적인 요인과 사회변화에 따른 상징적인 요인 역시 불평 등과 소외를 발생시켰다. 이와 같이 수직과 수평적인 축을 구성하고 있는 다양한 불평등의 요인 은 각기 독립적으로 보이나, 실제로는 밀접하게 연관되어 있으며 오늘날 발생하고 있는 새로운 형태의 불평등을 야기하고 있다.

이처럼 볼리비아의 빈곤과 불평등은 위에서 언급한 다양한 요소들이 상호작용함으로써 발생 되고 있는 하나의 복합적인 현상으로 설명할 수 있으며, 다음에서는 빈곤의 추이, 사회경제적 구조, 지역, 인종별 갈등상황을 통해 볼리비아의 빈곤과 불평등의 특성에 대해 논의하고자 한 다.

본론에 앞서 볼리비아의 일반적인 특성을 간단히 언급한다면, 이 국가는 남미 중앙에 위치해 있고 페루, 칠레, 아르헨티나, 파라과이, 브라질 등 다섯 개의 인접국에 둘러싸여 있는 내륙국이 다. 국토면적은 한반도의 약 5 배에 해당하는 110 만 제곱킬로미터이며, 2010 년을 기준으로 약

16) Paz Arauco, Verónica, coord.(2010: 23-24) 
990만의 인구가 살고 있다. 지형적으로는 척박한 기후와 빈곤한 생활환경을 대표하는 서부 고 원지대와 아열대 기후에 속해 있고 비옥한 동부지대 그리고 열대 저지대로 구성되어 있다. 2001년 실시한 인구센서스에 의하면, 원주민으로 분류할 수 있는 인구는 전체의 $60 \%$ 에 달하 며, 라틴아메리카에서 원주민 비율이 가장 높은 국가 중 하나이다. 원주민도 다양하여 케츄아 (Quechua), 아이마라(Aymara), 과라니(Guarani), 치키따노(Chiquitano), 모헤뇨(Mojeño) 등 30 여개 종족과 언어가 공존하고 있다. 17$)$

\section{〈그림 2〉 볼리비아의 절대 빈곤비율 추이(\%)}

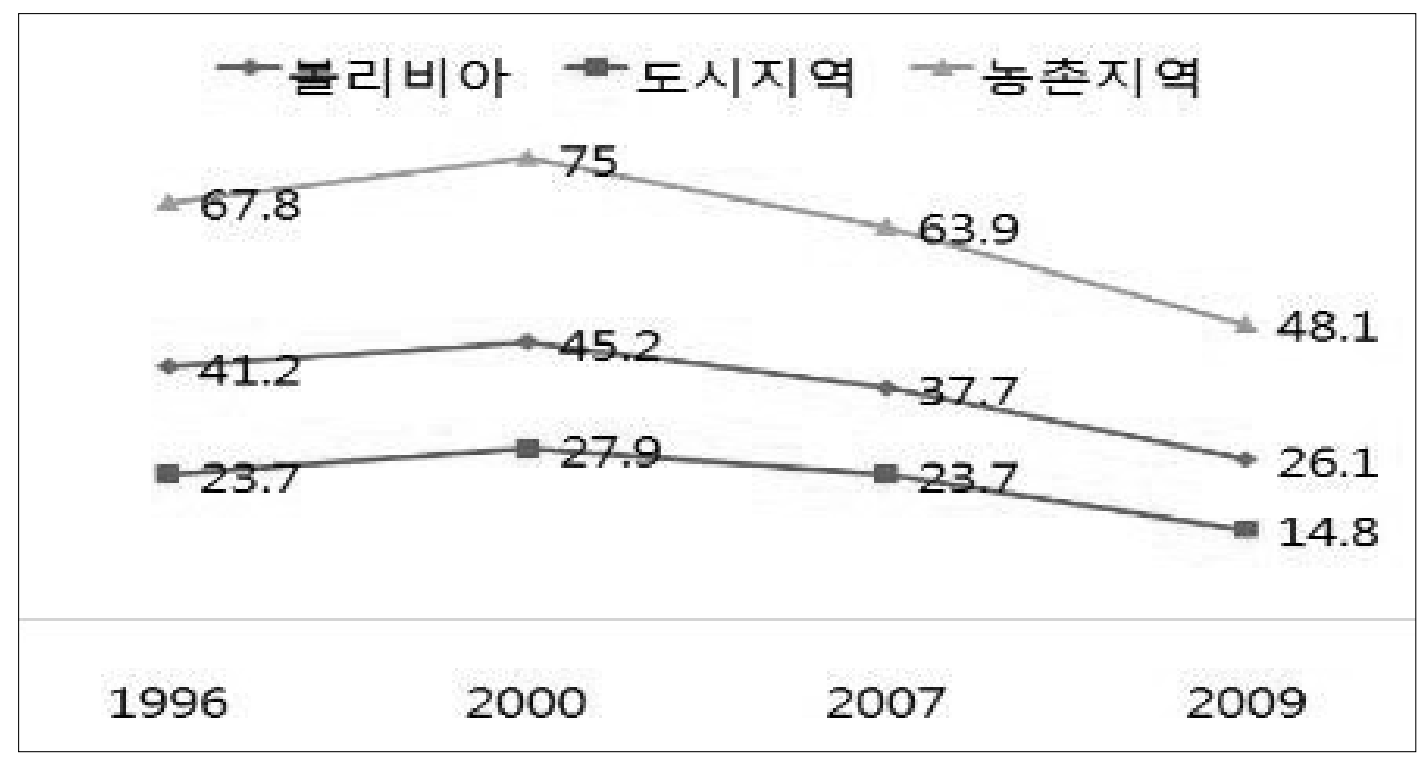

출처: UDAPE(2010); 관계부처합동(2012)

볼리비아는 2011년을 기준으로 1 인당 GDP가 2,421불이며18), 총 인구의 약 $48 \%$ 가 빈곤층에 해당된다. 〈그림2〉를 살펴보면, 1996년 41\%였던 절대빈곤 비율은 2009년 26\%로 감소했으나 여전히 역내의 타 국가보다 높은 수준이며, 특히 농촌지역 인구의 절반정도인 $48 \%$ 가 절대빈곤 계층에 속해 있다. ${ }^{19)}$ 한편, 볼리비아는 2006년 이래 평균 4\%이상의 경제성장을 달성해 왔으나

17) Drackner, Mikael(2009: 7); 관계부처합동(2012). 볼리비아의 원주민과 백인은 동일한 종족으로 보일 수 있으나, 거주 지역에 따라 원주민(indigenous: 아마존 저지대와 동부 차꼬에 거주)과 토착민(native people, 고지대와 알띠쁠라노, 계곡거주)으로 분류되며, 백인의 경우에도 출신지역에 따라 서부지역 백인(남미출신)과 동부지역 백 인(아르헨티나 출신)으로 구분된다.

18) World Bank, http://www.data.worldbank.org/indicator(2011년 7월 2일).

19) UDAPE(2010: 30-31); 관계부처합동(2012) 참조. 
역사적으로 자원배분과 관련하여 지역과 계층 간 불평등한 구조를 보유함으로써, 취약계층의 실질적인 경제, 사회지표는 크게 개선되지 않았다. 2011년을 기준으로 $\left.\mathrm{HDI}(0.663)^{20}\right)$ 와 지니계 수(World Bank, 57.0)등의 통계로 볼 때, 여타지역에 비해 사회지표가 낮고 불평등 정도가 심 각하며 가계소득 집중화 현상도 지속되고 있다. ${ }^{21)}$

일반적으로 국제기구에서는 볼리비아의 빈곤이 1 차 산품 중심의 수출 의존적인 경제구조, 비 공식 부문에 종사하는 높은 노동인구 비율, 사회에 만연한 부패, 소수 계층에 정치, 경제 권력이 집중되면서 발생하고 있다고 지적하고 있다. ${ }^{22)}$ 한편, 볼리비아 정부의 국가발전계획(Plan Nacional de Desarrollo 2006-2011)에 의하면, 최근 10년 동안 신자유주의 정책 하에 이루어 진 1차 산품 수출에 의존적인 정치, 경제 모델이 볼리비아의 빈곤과 불평등의 주요한 원인이 되 었다고 언급하고 있다. ${ }^{23)}$

라틴아메리카의 여타 국가들처럼, 볼리비아의 초기 빈곤원인은 스페인 식민기간 동안 장기간 에 걸쳐 심화되어 온 취약계층의 정치, 경제권에 대한 소외와 불평등, 그리고 그것이 구조화되 는 과정에서 발생하였다. 토지에 대한 접근권과 천연자원개발 수익권 등 자원배분은 역사적으 로 불평등하게 이루어져 왔으며, 이에 따라 정치와 경제 권력은 소수의 기득권 계층에게 집중되 었다. 그후 원주민과 백인 이주민들이 서부 고원과 동부 평야지대에 각각 거주하면서 수십년 동 안 인종간의 대립구도가 형성되었다.

신자유주의 정책 이후에는 토지와 자원이 집중된 동부지역24)이 경제적인 권력을 장악하게 되 었고, 이러한 배경에서 인종간의 갈등과 더불어 지역간 정치폭력과 충돌이 지속적으로 발생하 였다. 또한 노동시장에서 공식부문과 비공식 부문의 대두, 전문직과 비전문직 종사자간의 격차 가 확대되면서 노동시장에서 계층화가 이루어졌으며, 이러한 갈등의 이면에 정치, 이념적인 요

20) UNDP(2011), Human development index and its components, http://www.hdr.undp.org.(2012년 7월 5 일). 볼리비아의 HDI는 187 개국 중 108위이며, 이는 라틴아메리카 평균(0.731)보다 낮은 지수이다.

21) Paz Arauco, Verónica, coord.(2010: 27). 1970-1974년 전체소득에서 상위 20\%가 차지하는 비율은 59\%였 으며, 2007년 이 비율은 $60 \%$ 로 소폭 증가하였다. 한편, 동기간 전체소득에서 하위 $20 \%$ 가 차지하는 비율은 $4 \%$ 에서 $2 \%$ 로 감소하였다.

22) Drackner, Mikael(2009: 4).

23) Ministerio de Planificaci?n del Desarrollo(2006) 참조.

24) 관계부처합동(2012) 참조. 볼리비아는 동부지역(산타크루즈, 베니, 판도, 타리하)을 중심으로 경작지, 대규모 농산 업, 광물자원이 집중되어 있다. 산따끄루즈, 베니, 빤도는 전체 경작지의 $77 \%$ 를 보유하고 있으며, 따리하에는 전 체 천연가스 매장량의 $85 \%$ 가 집중되어 있다. 
소가 더해지면서 그 양상이 좀 더 복합적으로 변하게 되었다. ${ }^{25)}$

〈표2〉의 지역별 통계에 의하면, 동부와 서부지역을 중심으로 큰 폭의 빈부격차가 발생하고 있 음을 볼 수 있다. 동부의 대표적인 대도시인 산따끄루주(Santa Cruz)의 극빈층 비율은 25\%이 지만, 서부고원에 위치하고 있는 뽀토시(Potosí, 66.7\%), 라빠즈(La Paz, 42.2\%), 츄끼사까 (Chuquisaca, $61.5 \%$ )의 극빈층 비율은 국가평균(40.4\%)을 상회하고 있다. 이러한 동부-서부 등 지역별 차이와 원주민-비원주민 간의 인종적 격차는 빈곤비율 뿐 아니라, HDI, MDGs, 그 외 기초사회 서비스 등 관련지표에서 공통적으로 나타나고 있다. ${ }^{26)}$ 즉, 원주민 비율이 높고 서 부지역의 농촌인 경우와 원주민 비율이 낮은 동부지역의 도시 간 격차가 지속되고 있다. 또한 경작지, 대규모 농산업과 광물자원이 집중되어 있는 동부의 산따그루즈, 베니, 빤도, 따리하에 는 인구의 $35 \%$ 가 거주하지만 이 4 개주생산액은 전체 $\mathrm{GDP}$ 의 $67 \%$ 를 차지하고 있으며, 1 인당 소득은 볼리비아 평균 (1,619불)보다 높은 2,023불을 기록하고 있다. ${ }^{27)}$

〈표 2〉볼리비아 지역별 통계

\begin{tabular}{l|c|c|c|c|c}
\hline \multicolumn{1}{c|}{ 지 역(주) } & $\begin{array}{c}\text { 인 구 } \\
\text { (2009) }\end{array}$ & $\begin{array}{c}\text { 원주민 비율 } \\
\text { (2001) }\end{array}$ & $\begin{array}{c}\text { 1인당 국민소득 } \\
\text { (달러, 2009) }\end{array}$ & $\begin{array}{c}\text { 빈곤비율 } \\
\text { (2001) }\end{array}$ & $\begin{array}{c}\text { 극빈층 비율 } \\
\text { (2001) }\end{array}$ \\
\hline 베니(Veni) & 437,636 & 32.8 & 1,049 & 76.1 & 41 \\
\hline 뽀토시(Potosí) & 784,265 & 83.9 & 1,352 & 79.7 & 66.7 \\
\hline 빤도(Pando) & 78,250 & 16.2 & 2,000 & 72.5 & 34.7 \\
\hline 산타끄루즈(Santa Cruz) & $2,706,465$ & 37.5 & 1,693 & 38.1 & 25.1 \\
\hline 꼬차밤바(Cochabamba) & $1,824,082$ & 74.4 & 1,389 & 54.9 & 39 \\
\hline 라빠스(La Paz) & $2,798,653$ & 77.5 & 1,451 & 66.3 & 42.2 \\
\hline 추끼사까(Chuquisaca) & 640,768 & 65.6 & 1,196 & 70.1 & 61.5 \\
\hline 따리하(Tarija) & 509,708 & 19.7 & 3,353 & 50.8 & 32.8 \\
\hline 오루로(Oruro) & 447,468 & 73.9 & 1,489 & 67.8 & 46.3 \\
\hline 볼리비아 전체 & 10,227299 & 62.0 & 1,619 & 58.6 & 40.4 \\
\hline 츨
\end{tabular}

출처: UDAPE(2010); 문남권(2009); 관계부처합동(2012)을 토대로 필자 재작성

25) 문남권(2010: 270)

26) Drackner, Mikael(2009: 7 8). 볼리비아는 원주민 비율이 높은 국가이며, 이들은 역사적으로 취약 계층에 속 했다. 비 원주민과 비교할 때 경제, 사회지표가 전반적으로 낮고 이들은 토지권, 자원개발과정 및 수익배분 등에 서 소외되어 왔다.

27) 문남권(2010: 286-287) 
*지역별 원주민과 빈곤비율의 경우, 최근 통계가 부재하여 2001년 실시한 인구센서스의 자료 를 인용함.

2005년 볼리비아 역사상 최초의 원주민 대통령인 에보 모랄레스 아이마(Evo Morales Ayma)의 당선과 2009년 그의 재선, 그리고 현재까지 볼리비아에서는 정치, 경제적인 변화가 급격히 진행되고 있다. 볼리비아 정부 프로그램(Programa de Gobierno 2010-2015)에 의하 면, 현 정부는 신자유주의 정책의 잔재를 없애고, 1 차 산품 수출 의존적인 현재의 경제구조를 혁 신하기 위한 정책들을 추진하고 있다. 또한 부의 재분배와 소외계층의 기회창출을 위해 천연가 스를 비롯한 전략적인 자원에 대한 국가권한을 강화하면서, 이를 통해 창출된 재원을 바탕으로 사회복지 정책을 강력히 추진하고 있다. ${ }^{28)}$ 2009년 1월에 통과된 신헌법에서는 볼리비아를 다 민족(Plurinational)국가로 규정하고 있으며, 헌법상에도 36 개 언어를 공식적으로 인정하고 있 다. 이를 통해 우리는 인종, 언어, 문화적인 다양성을 기반으로 상호문화성(intercultural)과 다 원주의를 강조하는 현 정부의 정책방향을 볼 수 있다. 이와 같이 에보 모랄레스 정부는 국가의 정체성을 새롭게 정의하면서 원주민 등 다양한 취약계층을 포용하기 위한 개혁을 추진하고 있 으나, 이러한 과정에서 정치 소요와 폭력사태가 발생하면서 사회계층, 지역, 인종 간의 대립과 갈등이 반복되고 있는 위기상황에 직면해 있다.

\section{4. 사회정책에 함의된 시사점과 국별협력전략 지원방안}

라틴아메리카의 지속가능한 발전을 위해 불평등 개선은 여전히 최우선 과제로 고려되고 있으 며 UNDP 보고서에 언급했던 것처럼, 이 지역에서 추진되어 왔던 사회정책은 일부 국가에서 부 분적으로 성공을 거둔 것으로 평가되고 있다. 따라서 이 장에서는 빈곤과 불평등을 개선하기 위 해 추진되어 왔던 사회정책의 사례를 파악하고 그 유형과 특성에 대한 분석을 통해 이러한 사례 에 함의된 시사점을 도출하고, CPS에서 한국의 지원방안을 제시하고자 한다.

앞장에서 언급했던 것처럼, 세대를 걸쳐 지속되고 있는 라틴아메리카, 그리고 볼리비아의 다 차원적인 빈곤과 수직, 수평적인 불평등은 소득과 교육에 대한 접근기회 부족, 사회 구조적인 모순, 제도적 측면의 미비점 등과 밀접한 연관성을 보이고 있다. 또한 빈곤과 불평등은 개별국

28) MAS-IPSP(2010) 참조. 
가의 역사, 정치, 경제, 사회적인 상황과도 깊은 관련성을 가지고 있다. 따라서 라틴아메리카 국 가들은 정부체제와 사회적인 맥락에 대한 고려 하에 다양한 정책들을 수립해 왔으며, 일반적으 로 한 국가의 사회정책에는 정부의 역할, 경제정책의 방향, 시대별 달리 정의되어 온 부와 빈곤 의 개념, 그리고 재분배 모델에 대한 정치이념 등이 반영되어 있다.

우선 산업화 초기 단계에서 정부는 필요한 인적자원의 역량을 강화하기 위해 각기 다른 수준 에서 교육제도를 확대하고, 도시지역의 확장과 인구증가로 인해 발생하는 문제를 해결하기 위 해 주택과 공공보건 정책 및 사회 안전 제도를 추진하였다. 이외에도 최소임금제 도입, 고용계 약과 해고조건 강화 등 고용안정을 위한 대책도 강구하였다.

신자유주의 정책 하, 정부는 경제발전을 통한 빈곤완화를 강조하면서 극빈계층에 한정하는 사 회지원 프로그램과 구조조정 및 경제위기와 자연재해 발생 시, 가장 큰 피해를 입을 수 있는 취 약계층을 중심으로 사회정책을 추진함으로써 당시 정부 역할은 미니멀리즘(minimalism)29)으 로 비유되고 있다. 이처럼 이 시기에 이루어진 경제적인 성과는 적절한 소득분배와 직결되지 않 은 한계를 노출하면서 전반적으로 사회지표가 후퇴했으며, 특히 상당수의 중산층이 몰락하는 현상이 나타나게 되었다. ${ }^{30)}$

1990년 중반이래, 라틴아메리카의 각 국가들은 경제발전을 통한 빈곤감소라는 기존의 입장을 더 이상 고수할 수 없었다. 또한 일부 국가에서 등장하기 시작한 좌파와 중도좌파(브라질, 아르 헨티나, 칠레, 우루과이) 정부 주도로 남미공동시장(MERCOSUR)에서는 자유무역과 같은 경제 문제에서 사회정의와 재분배 정책 등을 주요한 논의사항으로 고려하기 시작하였다. ${ }^{31)}$ 이러한 상황에서 사회부문에 대한 공공투자가 증가했으며, 빈곤과 불평등의 원인을 고려한 종합적인 성격의 정책들이 수립되기 시작하였다.

다음 〈표3〉은 라틴아메리카에서 추진되어 왔던 사회정책들의 사례를 프로그램의 목적, 지원 대상, 내용에 따라 유형별로 분류하였다. 이처럼 라틴아메리카의 사회정책은 다음과 같이 다섯 가지 유형으로 분류되고 있다. ${ }^{32)}$ 첫째는 위기 시, 취약계층에게 발생할 수 있는 부정적인 효과

29) Arriagada, Irma(2006: 9-12). 이는 최소한의 요소를 투입하여 최대한의 효과를 얻으려 했던 당시 정부의 역할 을 비유한 표현이다.

30) Solimano, Andr?s(2005: 47-48).

31) Sung Hyong, Rhee(2011: 16-18).

32) Pardo, Marcia(2003: 14-32). 
를 예방, 대처, 완화하기 위한 정책이며, 이 범주에는 실업급여와 긴급고용 프로그램 등이 속한 다. 둘째는 소득이 부족한 사람을 대상으로 조건, 무조건적인 현금지급, 식량과 그 외의 물자 등 을 지원하는 정책이다. 셋째는 취약계층의 소득창출과 역량강화에 초점을 둔 정책으로 고용프 로그램과 직업훈련 프로그램 등이 이 분류에 해당된다. 네 번째 유형은 1980년대 구조조정의 결과, 부정적인 영향을 최소화하기 위해 일시적으로 운영되었다가 그 후 영구적인 성격으로 전 환된 프로그램들이며, 특히 신자유주의 정부 하에 추진되었다. 마지막으로 여성, 원주민, 아동, 여성가장 등 이 지역의 취약계층으로 고려되고 있는 특정그룹을 대상으로 이들의 다양한 수요 와 개별그룹의 특성을 반영한 정책이다.

이중 주목할 만한 정책은 두 번째로 언급한 CTP이다. 이 프로그램은 1990년대 후반 이래, 중 도좌파 정부의 주도로 추진되어온 사회정책의 일환이며 빈곤퇴치와 소득 재분배를 목적으로 하 고 있다. 이 정책의 특성은 빈곤계층의 가정, 청소년 등 취약계층에게 직접적으로 현금을 지원 함으로써 이들의 역량을 강화하고 삶을 개선시키는 것이다. ${ }^{33)}$ 또한 세대적인 차원에서 지속되 고 있는 이 지역의 빈곤과 불평등의 원인을 고려하여 이러한 악순환이 단절될 수 있도록 가정단 위에 초점을 두고 실시되어 왔다. CTP의 성공사례로는 브라질의 볼사 파밀리아(Bolsa familia), 칠레의 솔리다리오(Solidario), 멕시코의 오뽀르뚜니다데스(Oportunidades) 등이 언급된다. 브라질의 볼사 파밀리아는 빈곤층 가정에게 일정금액을 지원하는 대신, 이들이 자녀 를 학교에 보내고 예방 접종을 시키는 등 특정사항을 지원의 조건으로 제시하고 있으며, 이를 이행하도록 하고 있다. 2005 년을 기준으로 이 프로그램을 통해 브라질 전체인구의 $25 \%$ 에 해당 되는 약 1 천백만 가구(5천 200 만명에 해당)가 혜택을 받은 것으로 알려져 있다. 칠레의 솔리다 리오는 CTP로 분류되나 종합적인 특성을 지니고 있으며, 조건부 현금지급 외에도 심리적인 지 원과 사회지원 프로그램이 구성요소로 포함되어 있다. 멕시코의 오뽀르뚜니다데스는 1997년 쁘 로그레사(Progresa)라는 이름으로 도입되어 농촌지역에 한정되어 실시되었으나, 2001년 현재 의 이름으로 변경되면서 도시지역까지 지원을 확대했으며, 최근에는 국제 식량가격의 상승으로 에너지, 식량, 노년층 등 지원영역과 그 대상을 넓혀가고 있다.

33) UNDP(2010: 110-112). 


\section{〈표 3〉라틴아메리카 사회정책의 유형}

\begin{tabular}{|c|c|c|}
\hline 정책유형 & 목적 & 프로그램 내용 \\
\hline $\begin{array}{l}\text { (1) 사회적 위험과 } \\
\text { 취약성 관리 }\end{array}$ & $\begin{array}{l}\text { 경제위기와 자연재해 발생 시, } \\
\text { 취약계층에게 발생할 수 있는 } \\
\text { 부정적인 영향의 예방, 대처, } \\
\text { 완화 }\end{array}$ & $\begin{array}{l}\text { 실업급여, 긴급고용 프로그램, } \\
\text { 사회보장 및 위기, 직접적인 사 } \\
\text { 회적 지원, 긴급 사회지원 등 }\end{array}$ \\
\hline (2) 사회적 혜택 & $\begin{array}{l}\text { 소득이 충분치 않은 계층을 대 } \\
\text { 상으로 이들이 기본적인 물품 } \\
\text { 과 서비스에 접근할 수 있도록 } \\
\text { 지원 }\end{array}$ & $\begin{array}{l}\text { 조건, 무조건적인 직접 현금 지 } \\
\text { 급, 식량과 그 외 물자지원 등 }\end{array}$ \\
\hline $\begin{array}{l}\text { (3) 생산과 고용에 } \\
\text { 초점을 둔 공공 } \\
\text { 프로그램 }\end{array}$ & $\begin{array}{l}\text { 전통적인 사회정책과는 달리, } \\
\text { 빈곤극복을 위해 취약계층의 } \\
\text { 역량강화와 소득창출에 지원 }\end{array}$ & $\begin{array}{l}\text { 고용프로그램, 직업능력강화, } \\
\text { 생산프로젝트, 대출과 소액대출 } \\
\text { 접근, 자영업 추진 등 }\end{array}$ \\
\hline (4) 사회투자기금 & $\begin{array}{l}\text { 80년대 구조조정으로 발생한 } \\
\text { 부정적인 영향을 최소화하기 } \\
\text { 위해 일시적으로 운영되다가 } \\
\text { 영구적인 성격으로 전환 }\end{array}$ & $\begin{array}{l}\text { 기본적인 사회 인프라 구축, 주 } \\
\text { 거, 지역사회단체 강화 등 }\end{array}$ \\
\hline $\begin{array}{c}\text { (5) 특정 사회계층을 } \\
\text { 위한 프로그램 }\end{array}$ & $\begin{array}{l}\text { 취약계층의 다양성 고려, 특정 } \\
\text { 그룹의 수요와 요청을 반영한 } \\
\text { 정책수립 }\end{array}$ & $\begin{array}{l}\text { 아동, 청소년, 여성가장, 장애 } \\
\text { 인, 노년층, 특정 인종그룹, 침 } \\
\text { 체된 생산부문 등 }\end{array}$ \\
\hline
\end{tabular}

출처: Pardo, Marcia(2003)

볼리비아의 경우, 2006년 에보 모랄레스 정부 수립 이후에 두개의 대표적인 CTP가 도입되었 으며 이러한 프로그램들은 자원에 대한 국가권한을 강화함으로써, 이를 통해 창출된 재원을 바 탕으로 운영되고 있다. 다음 박스에 설명되어 있는 보노 후안시또 삔또(Bono Juancito Pinto) 의 지원대상은 빈곤층 가정의 1학년에서 8학년 공립학교 재학생(18세 미만), 대안학교 청소년과 특수학교 학생이다. 정부는 이들이 교육과정에서 일탈하지 않도록 학용품, 교통비, 식비, 기타 비용 등 교육과 관련된 일정 금액을 지원하고 있다. 2008년 본 프로그램의 수혜학생 수는 180 만명이었고, 2015년까지 그 숫자는 220만명에 이를 것으로 전망되고 있다. ${ }^{34)}$ 본 프로그램은 빈곤층 가정 학생의 공립학교 참여, 아동노동 방지, 초등교육 이수율 개선을 목표로 하고 있으 며, 세대 간에 재생산 되고 있는 빈곤의 악순환을 단절하기 위해 실시되고 있다. 또 다른 프로그

34) MAS-IPSP(2010: 124). 
램인 후아나 아수르두이(Juana Azurduy)는 2009년에 도입되었고, 건강보험 혜택을 받지 못 하고 있는 산모와 2세 이하 영유아를 대상으로 모자보건 사망률과 영유아의 만성적인 영양부족 개선을 위해 실시되고 있다. ${ }^{35)}$

물론 이러한 CTP에 대한 비판도 존재한다. 즉, 실질적으로 소득이 재분배되기 위해서는 조세 정책과 토지개혁 등 좀 더 근본적인 대책이 모색되어야 하며, CTP와 같이 한정된 계층을 위한 단기성 사회정책은 전반적인 제도개선과 사회구조를 변화시키데 한계가 있다는 논리이다. 또한 이러한 정책들은 특정정부의 강력한 의지 하에 실시되기 때문에 정부나 정책 방향이 변하거나, 국가경제가 침체되어 재원이 부족해질 경우에는 정책의 지속가능성이 보장되기 어려운 단점이 있다. 이외에도 정부가 프로그램을 효율적으로 운용하지 않는다면, 빈곤층의 근본적인 문제를 개선하기보다는 단순한 시혜성 수단으로 변질될 수 있다는 우려도 있다.

\section{보노 후안시또 삔또(El Bono Juancito Pinto)}

\section{목표}

- 세대간에 전달되는 빈곤의 재생산 단절

- 공립학교 참여율과 초등교육 이수율 개선

- 학생 교육을 위해 소요되는 학용품, 교통비, 식비, 기타 비용지원

-MDGs목표 중 초등교육의 보편화에 지원

수혜 대상

- 공립학교 1학년부터 8학년 재학생(아동, 18 세 미만 청소년 포함), 대안학교 청소년, 특수학교 학생(연령제한 없음)

선정기준과 지원규모

- 해당학기 등록학생

- 학기동안 정기적인 출석자

• 학생 한명 당 연간 200 볼리비아노(미화 26불에 해당)지원

달성효과

- 재분배: 수혜학생의 평균 $75 \%$ 는 빈곤층 가정출신

- 교육확대: 초등학교 1학년 등록비율 개선, 학업중단과 지체비율 감소

사용처

• $65 \%$ 는 학생에게 직접적으로 지원, $20 \%$ 는 직접적인 교육비용(학용품과 교통비) 지원

출처: UNDP(2010); División de Desarrollo Social, CEPAL(2011)

35) CEPAL(2011), Programa de transferencias condicionadas, http://www.dds.cepal.org(2012년 7월 12일). 
따라서 이러한 CTP 등 사회정책의 주요한 성공요소는 다음과 같이 언급되고 있다. ${ }^{36)}$ 첫째, 이러한 정책은 가정단위에 초점을 두고 보건, 교육 분야 등 부분적인 개별과제를 개선하기보다 는 통합분야 및 범분야 과제를 포괄할 수 있는 종합적인 공공정책으로 수립되어야 한다. 둘째, 수혜자의 필요와 목표를 우선적으로 반영하며 역량강화와 고용기회 확대에 중점을 두어 프로그 램 종료 이후 이들이 생산적이고 안정된 직업에 고용될 수 있도록 해야 한다. 셋째, 수혜자 선정 기준이 명확하고 투명해야 한다. 넷째, 프로그램에 대한 평가와 모니터링 지표가 객관성을 보유 해야 하며, 마지막으로 본 프로그램의 효과가 정치적인 수단으로 활용될 위험성을 배제하는 것 도 중요하다. 이러한 측면에서 최근 사회정책들은 지원 분야, 취약계층의 범위, 지원수단 등이 확대되면서 포괄적인 성격의 공공정책으로 변화하는 경향을 보이고 있다. ${ }^{37)}$

그렇다면 왜 우리는 현재 라틴아메리카에서 폭넓게 시행되고 있는 사회정책의 흐름과 특성을 고려해야 하며, 특히 CTP 등 주요 사회정책에 함의된 시사점은 무엇일까?

앞에서 살펴본 것처럼, 대부분의 사회정책은 각국의 맥락에 맞게 발전되어 왔으며, 국가의 역 사, 전통, 규범, 정치제도, 경제발전 수준, 이념적인 특성, 그리고 시대별 국가가 선호하는 정책 방향이 포괄적으로 반영되어 있다. 따라서 우리는 이러한 사회정책에 대한 분석을 통해 국가별 로 우선순위에 두고 있는 개발과제, 취약계층의 범위, 빈곤과 불평등의 개념, 소득 재분배를 위 해 채택하고 있는 정책모델, 그리고 이러한 모델에 반영되어 있는 정치적인 이념까지 파악할 수 있다. 이러한 의미에서 라틴아메리카와 같이 다양한 국가로 구성된 대륙일 경우, 국가별로 특성 화된 정책과 전략을 구축하기 위해서는 이들의 시각이 반영되어 있는 사회정책의 유형과 특성 을 분석하고, 이를 정책 수립 시 반영할 필요성을 제기한다. 특히, 라틴아메리카는 전반적으로 경제, 사회발전 지표가 양호한 중소득국가로 구성되어 있으며, 실제 성공한 사례로 평가되고 있 는 정책들도 있어 우리도 직접적으로 지원할 수 있는 유용한 프로그램들이 존재하고 있다.

따라서 라틴아메리카에서 성공했다고 평가되고 있는 $\mathrm{CTP}$ 의 사례를 통해 사회정책에 함의되 어 있는 시사점을 고찰하고자 한다. 우선, 이러한 사회정책에 직접적으로 지원하는 방안은 원조 효과성 제고를 위한 국제사회의 주요 원칙과도 부합되고 있다. CTP는 앞에서 언급했던 것처럼, 소액이지만 빈곤계층에 직접적으로 지원함으로써 빈곤층의 수요를 우선적으로 반영할 수 있다.

36) UNDP(2010: 115-116).

37) Pardo, Marcia(2003: 31-34). 지원 분야는 기존의 보건, 교육 등 다양한 분야를 포괄적으로 고려하고 있으며, 취약계층도 원주민과 저소득층에서 여성, 여성가장, 노년층 등 새로운 계층으로 확대되고 있다. 한편 지원수단도 단순 보조금에서 기술지원 등 다양한 형태로 그 범위를 넓혀가고 있다 
또한 여기에는 지역주민이 이미 알고 있는 경험과 기술을 효과적으로 사용하는 노동집약적인 발전방안이 활용됨으로써, 프로그램의 기획 단계부터 빈곤층 의견을 수렴하는 것이 용이하 다. ${ }^{38)}$ 특히, 브라질의 볼사 파밀리아는 관료적인 제도를 정비하고 지방정부와 시 정부의 권한 을 확대하는데 기여했으며, 프로그램의 진행, 평가와 모니터링 과정에 지역주민과 지역단체의 의견이 개진되고 이들이 직접 참여할 수 있는 길을 열었다는 점에서39) 평가받고 있다. 칠레의 솔리다리오 경우 프로그램 수립 시, 수혜자 시각에서 이들의 필요가 우선적으로 반영되었으며 특히 2 년에 걸쳐 진행되는 심리지원 프로그램의 경우에는 사회 복지사가 빈곤층 가정과 함께 빈곤으로부터 탈출할 수 있는 전략을 수립하고, 사회적 지원의 다양한 영역을 공동으로 개발하 는 내용으로 구성되어 있다. ${ }^{40)}$ 이와 같이 이러한 프로그램들의 의의는 빈곤층이 정책대상이 아 닌 참여자로서 역할하고 있다는 점이다.

이러한 시각에서 볼 때, 수원국이 기존에 수립한 사회정책이 효율적으로 운용될 수 있는 환경 과 제도가 구축된다면 빈곤층 개인, 수원국과 지역의 다양한 공동체의 참여가 활성화 될 수 있 으며, 이를 통해 수원국 측의 주인의식이 고취되고 이들의 역량이 강화될 수 있다. 또한 주요한 사회정책은 국가발전계획과의 연계를 통해 수립되고 있으므로 이를 직접적으로 지원한다면 수 원국의 개발과제를 우선적으로 반영하는 지원이 될 수 있으며, 이러한 정책에 지원하고 있는 기 존 타 공여국과의 협력도 용이할 수 있다. 이외에도 주요한 사회정책에는 수원국 측에서 설정한 출발점, 목표, 결과 등 관련지표가 명확히 제시되어 있고, 이에 따라 프로그램의 목표 대비 달성 현황을 정량적으로 측정할 수 있어, 이는 결국 성과관리에 기반을 둔 지원과도 연결될 수 있다.

마지막으로 본 글에서는 볼리비아의 사례를 통해 사회정책에 함의된 시사점을 도출하고, $\mathrm{CPS}$ 에서 고려할 수 있는 지원방안을 제시하고자 한다.

브라질, 칠레, 멕시코의 사례와 비교할 때, 볼리비아의 $\mathrm{CTP}$ 는 교육과 보건 분야에 한정되어 개별과제를 개선하는 것에 목표를 두고 있다. 보노 후안시또 삔또는 전반적으로 초등교육 이수 율 개선을 목표로 하고 있으나, 이들의 역량강화나 본 프로그램의 종료 이후 수혜자를 위한 고 용기회 제공 등 빈곤개선을 위한 근본적인 대책과는 연계성이 미흡하다. 또한 수혜자 가정의 의 무사항 이행 여부를 컴퓨터 데이터베이스로 점검하는 멕시코의 오뽀르뚜니다데스와는 달리 이

38) 박윤주(2011: 180-181). 필자는 이러한 프로그램이 경제발전을 통해 일자리를 창출하고 고용을 통해 빈곤과 불평 등을 해소하는 시장주의적인 입장과는 달리, 빈곤층에 직접 지원하고 이들이 필요로 하는 삶의 질 개선을 추구 한다는 측면에서 참여적 발전(participatory development)의 접근법으로 분석하고 있다.

39) 박윤주(2011: 181)

40) UNDP(2010: 116 117). 
프로그램에는 수혜자 이행사항, 이에 대한 점검, 출구전략 수립 등 세부적인 기준이 제시되고 있지 않다.

볼리비아의 국가발전계획과 정부프로그램에는 자원의 고부가가치 창출, 1 차 산품에 의존하는 취약한 경제구조 혁신, 생산적인 고용 중심의 성장, 안정적인 직업창출을 통한 불평등 감소를 강조하고 있으며 특히, 사회정책과 관련하여 보노 후안시또와 핀또, 후아나 아수르두이와 같은 빈곤퇴치 프로그램을강화하여 취약계층의 보건과 기초사회 서비스 접근성을 개선하고 이들의 직업기회 창출을 강조하고 있다. ${ }^{41)}$ 실제로 2006년 에보 모랄레스 정부 수립 이후, 천연가스와 광물 등 볼리비아의 주요 수출품 가격이 상승하면서 볼리비아는 양호한 경제성장률을 유지해 왔으며 이러한 재원을 바탕으로 추진되어왔던 사회정책들은 경제, 사회 환경을 개선하는데 부 분적으로나마 공헌한 것으로 평가되고 있다.

한편, 볼리비아를 지원하고 있는 타 공여국들은 이제까지 이들의 지원이 볼리비아의 거시적인 환경을 개선하는데 주력해 왔으나, 향후에는 미시적인 차원에서 특정지역, 취약계층, 개선정도 가 미미한 부분을 중심으로 특화(targeting)된 지원과 정책 및 제도적인 측면을 강화하는 것이 필요하다고 언급하고 있다. ${ }^{42)}$

이와 같이 한국은 이미 볼리비아의 제도 내에 구축되어 있는 정책 및 프로그램과 연계하여 통 합적인 전략을 수립함으로써, 장기적인 시각에서 볼리비아의 정치, 경제, 사회구조의 전환과정 을 지원하는 것이 필요하다. 따라서 볼리비아 CPS에 한국의 중점 분야로 제시되어 있는 교통, 농업, 보건 분야 내에서 추진되고 있는 주요한 사회정책을 파악하고, 이에 대한 연계성을 고려 한 지원이 필요하다. 또한 비교적 시스템이 효율적으로 구축되어 있으며, 타 공여국의 경우에도 이러한 프로그램에 직접적인 재정지원을 하고 있다면 우리도 그들과 함께 동일한 지원형태를 고려할 수 있다. 실제로 볼리비아 CPS에 기술되었던 것처럼, 타 공여기관들은 교육, 물, 교통 분야 내 수립되어 있는 프로그램에 직접적으로 공동재정 지원을 추진하고 있으며 이러한 형태 는 초기단계에 있지만 증가하는 추세이다. 이외에도 볼리비아에는 볼리비아 개발을 위한 파트 너 그룹(Grupo de Socios para Desarrollo de Bolivia: GruS)43)이라는 공여국 협의체가 운

41) Ministerio de Planificaci?n del Desarrollo(2006); MAS-IPSP(2010).

42) 관계부처합동(2012: 국제사회의 원조동향) 참조.

43) GruS(Grupo de Socios para el Desarrollo de Bolivia), http://www.grus.org(2011년 8월 23일). 16개 양 자 공여국과 7 개 다자간 협력기구로 구성되어 있는 공식 회의체로서, 공여기관 간 협력과 조정을 추구하기 위해 설치되었고, 한국은 2011년 7월 21일 회원국으로 가입하였다. 현 단계에서 이 협의체는 정보교류 차원에서 운영 되고 있으나, 향후에는 기능이 향상될 것으로 전망된다. 
용되고 있으며, 이처럼 타 공여국과의 원조조화를 위한 유효한 체제를 보유하고 있다

이러한 환경을 고려한다면, 우리는 볼리비아 $\mathrm{CPS}$ 에서 지원이 가능한 정책을 발굴하고, 이에 대해 재정, 기술, 프로젝트 등 다양한 형태로 직접적인 지원을 고려할 수 있으며, 설령 직접적인 지원이 아니더라고 볼리비아의 사회정책에서 미비했던 부분을 중심으로 이에 대한 정책과 제도 개선을 위한 방안을 고려할 수 있다. 실례로 보노 후안시또 뻰또가 빈곤과 불평등 개선이라는 근본적인 대책과 연계될 수 있도록 우리는 이 프로그램에 교육, 연수프로그램, 직업훈련 프로그 램, 고용센터 설립 등을 추가적으로 지원하여 기존의 제도적인 미비점을 보완할 수 있다. 이외 에도 프로그램의 성공요소로 제시되고 있는 수혜자 선정 기준과 이행사항, 빈곤의 측정기준, 평 가와 모니터링 지표 등 관련한 통계의 구축과 분석 및 관리를 강화하기 위해 우리의 IT기술을 활용한 지원도 고려할 수 있을 것이다.

\section{5. 결론}

본 글에서는 일반적으로 국제개발협력의 시각에서 '빈곤' , '불평등' 의 문제에서 크게 주목받 지 못했던 라틴아메리카의 빈곤과 불평등 상황을 분석하고, 개별사례 국가로서 볼리비아의 빈 곤 그리고 불평등의 특수성을 고찰하였다. 라틴아메리카는 외형상 경제, 사회발전 지표가 양호 하므로 이러한 맥락에서 이들 국가의 빈곤과 불평등 문제는 크게 부각되지 않았다. 그러나 지금 까지 이루어진 경제성장은 라틴아메리카의 빈곤과 소득불평등 상황을 크게 개선시키지 못했으 며, 이것이 더욱 심각한 문제일 수 있다. 즉, 이 지역의 문제는 단순한 저생산성에서 비롯되고 있는 것이 아니라 역사, 정치, 경제, 사회의 구조적인 모순과 높은 연관성을 가지고 있다. 또한 대부분 개발문제의 근원은 빈곤과 불평등에서 시작되고 있는 현실을 감안한다면, 우리는 이 문 제에 대해 결코 소홀할 수 없다.

이와 같이 라틴아메리카 국가들은 이러한 문제를 극복하기 위한 방안으로 다양한 사회정책을 추진해 왔다. 따라서 이 글에서는 일부 국가에서 성공한 정책으로 평가되고 있는 사례를 분석하 여, 시사점을 도출하고 $\mathrm{CPS}$ 에서 가능한 지원방안을 제시하고자 하였다. 앞에서 언급했던 것처 럼, 이러한 사회정책을 지원하는 것은 지원의 방향성이 명확하고 국가의 우선순위와 특수성을 반영할 수 있으며, 수원국 정부와 지역주민의 적극적인 참여를 유도할 수 있다. 또한 원조조화 의 측면에서도 타 공여국과의 공동추진이 용이할 수 있다. 우리는 현 단계에서 비록 이들의 사 
회정책을 직접적으로 지원하고 있지 않지만, 최소한 이러한 정책에 대해 면밀히 분석 할 필요가 있다.

우리에게 라틴아메리카는 전통적으로 타 지역에 비해 관심과 비중이 적은 지역이었다. 그러나 오늘날 양 지역은 다양한 분야에서 협력기반을 강화해 가고 있는 추세이며 라틴아메리카의 주 요 공여국인 스페인 등 유럽에서 발생하고 있는 최근의 경제위기 상황을 본다면, 향후 이 지역 에서 우리의 역할이 더욱 중요할 것으로 전망된다. 한국은 국내외적으로 개발협력 체제의 급격 한 변화흐름에 대응하고 있으며, 국제사회의 합의된 원칙을 토대로 원조효과성 제고를 위해 노 력하고 있다. 이러한 맥락에서 본 글은 그들의 시각에서 문제를 해결하기 위해 모색해 왔던 정 책들을 분석하고 우리가 할 수 있는 지원방안을 제시하고자 했으며, 향후에도 우리의 지원이 유 효할 수 있는 이들의 프로그램을 발굴하여 이와 연계된 구체적인 지원방안에 대해 연구할 필요 성을 제기하면서 이 글을 마치고자 한다. 


\section{참고문헌}

\section{1. 국내문헌}

권기수 외(2007), 한국의 주요국별 · 지역별 중장기 통상전략: 중남미, 대외경제 정책연구원(KIEP) 관계부처합동(2012), 볼리비아 국가협력전략(CPS) 2012 2015, 제12차 국제개발협력 위원회 문남권(2010), “볼리비아 자치분쟁의 원인과 현황”, 중남미 연구, 제 28 권 2 호, 한국외국어대학교 박윤주(2011), “빈곤과 불평등”, 라틴아메리카의 어제와 오늘, 이담

윤택동 \& Nelson dos Reis, Carlos(2005), “라틴아메리카의 경제성장과 사회적 소외”, 이베 로아메리카 제 7 권, 1 호.

이상현(2007), 볼리비아의 자원민족주의와 천연가스산업 재편의 전개와 의미, 대외경제정책 연구원(KIEP)

정유아(2010), “국가지원전략(CAS) 프로세스 정형화방안”, KOICA개발정책포커스 no. 4 , 한국국제협력단(KOICA)

\section{2. 국외문헌}

Arriaga, Irma(2006), Cambios de las políticas sociales: políticas de género y familia, División de Desarrollo Social(DDS), CEPAL.

CEPAL(2010), Panorama social de América Latina, CEPAL

----------(2011), Panorama social de América Latina, CEPAL

Dina Nuñez, Ignacio(coord. 2004). Integración, democracia y desarrollo, retos para el siglo XXI, LibrosEnRed, Argentina

Drackner, Mikael(2009), Context analysis Bolivia, ORGUT Consulting AB for Forum Syd.

Lustig, Nora(2011), Inequality, poverty and public policy in Latin America, OECD, PPT자료 
MAS-IPSP, 2010-2015 Programa de Gobierno, Bolivia País Líder

Ministerio de Planificación del Desarrollo, Lineaminetoestratégico Plan Nacional de Desarrollo, Bolivia digna, soberana,productiva y democrática para vivir bien 2006-2010

Pardo, Marcia(2003), Reseña de programas sociales para la superación de la pobreza en América Latina, CEPAL.

Paz Arauco, Verónica, (coord., 2010), Los cambios detrís del cambio desigualdades y movilidad social en Bolivia, UNDP

Solimano, Andrés(2005), "Hacia nuevas políticas sociales en América Latina: crecimiento, clases medias y derechos sociales”, Revista de la CEPAL 87.

Sung Hyong, Rhee(2011), Geopolitical change and paradigm shift? 20 theses on the Latin American pathways on development, 한-UN 중남미경제위원회 경 제협력심층세미나, 제 15 차 한·중남미 비즈니스 포럼 PPT자료

Titelman, Daniel(2011), Latin America and the Caribbean as middle income region: Fostering links with the Republic of Korea, 한-UN 중남미경제위원회 경제협력심층세미나, 제 15 차 한 · 중남미 비즈니스 포럼 PPT자료

UN(2010), Objetivos de Desarrollo del Milenio, El progreso de América Latina y el Caribe hacia los Objetivos de Desarrollo del Milenio, desaf?o para lograrlos con igualdad, UN

UDAPE(Unidad de Análisis Políticas Sociales y Econ?micas(2010), Sexto informe de progreso de los Objetivos de Desarrollo del Milenio en Bolivia, Comit? Internacional Metas de Desarrollo del Milenio

UNDP(2010), Informe Regional sobre Desarrollo Humano para América Latina y el Caribe, UNDP

Weller, Jurgen(2011), A macroeconomic agneda for equality: towards a new fiscal covenant in Latin America, 한-UN 중남미경제위원회 경제협력심층세미나, 제 15 차 한-중남미 비즈니스포럼 PPT자료 


\section{3. 웹사이트}

CEPAL(2011), Programa de transferencias condicionadas, http://www.dds.cepal.org

DAC(2011), DAC list of ODA recipients, http://www.oecd.org

UNDP(2011), Human development index and its components, http://www.hdr.undp.org

INE(Instituto Nacional Estadística de Bolivia, 볼리비아 통계청), http://www.ine.gob.bo

GruS(Grupo de Socios para el Desarrollo de Bolivia, 볼리비아 개발을 위한 공여국 협의체), http://www.grus.org

World Bank, http://www.data.worldbank.org/indicator 